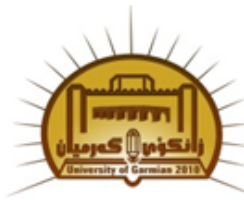

Available online at http://jgu.garmian.edu.krd

Journal of Uni versity of Garmian

https://doi.org/10.24271/garmian.1030

\title{
The role of motivation in developing autonomy among university EFL students in the Kurdistan Region of Iraq: Students' Attitudes
}

\author{
Salah B. Hussein, Fatimah R. Hasan Al Bajalani,
}

Department of English, University of Salahaddin

\section{Article Info}

Received: January, 2019

Revised:February,2019

Accepted:April,2019

\section{Keywords}

learner autonomy, motivation, Kurdistan Region of Iraq, EFL students, attitude.

\section{Corresponding Author}

Salah.khoshnaw@uor.edu.krd

\begin{abstract}
This study, which used a mixed-method approach, is an extract from a $\mathrm{PhD}$ thesis on the role of motivation in the effort to promote greater learner autonomy among university level EFL students, especially in terms of the Kurdish context in which the research was set. The research used the English Language Departments of the University of Salahaddin — situated in the Kurdistan Region of Iraq's capital city Erbil - the University of Sulaimani in Slemani, and the University of Duhok in Duhok as the study site. These were selected, as the subject of learner autonomy has not been regularly included as one of their learning objectives. The sample population was made up of 211 students. After a quantitative and qualitative analysis was conducted, the collected data showed there was a positive attitude toward the role of motivation in developing learner autonomy in principle but that this did not translate into its practical application by the students even though they displayed a strong desire to see themselves become autonomous learners.
\end{abstract}

\section{Introduction}

In the West, developing a learner's personal autonomy is central to their education system (Benson, 2011) and, indeed, the evidence is that this makes a significant contribution to a student's learning outcomes. However, in the Kurdistan Region of Iraq this ethos is new for many of its learning institutions and teaching professionals. MHE (2010) recognises that even though many of those who have watched the efforts by the Kurdistan Region of Iraq to make progress with regard to learner autonomy have praised the commitment that has been shown, it is firmly of the opinion that there remains a significant amount of work to do in order to make the Kurdish educational system comparable in terms of its teaching and attainment standards to the equivalent education providers in the West. That said; currently, the region is in the middle of undertaking a substantial change in its education policies by 
attempting to move its focus from the more traditional styles of teaching that have been espoused for generations to the modern, Westernised educational ideals. For Lu (2014), however, this transition period is an important process in the drive to develop and support learner autonomy/collaborative skills and that in order to do so, it is necessary to understand the teaching and learning practices that are in use currently.

Obviously, there is no doubt that the Kurdistan Region of Iraq's higher education system faces many serious problems, which in turn leads to questions about the competency of its administrators, teachers, and the appropriateness of the methods it chooses to instruct its students with. Indeed, it is apparent that there is no concerted policy in place that helps to develop students' abilities, even in terms of just being prepared for their lessons. Researchers who have investigated this largely blame the inflexible nature of the teaching system. Hassan and Jamaludin (2010, p.3), for instance state that it is standard throughout the Middle East for teachers to be entirely responsible for how effectively their class learns, which also means they are the sole decision-makers when it comes to the planning and preparation of their students' activities. Marzouk agrees, again noting that for the majority of the Middle East, education systems employ an instruction method that is based on memorisation and formal lectures, and that "Students are expected to memorise their textbooks word for word" (Marzouk, 2012). Such an approach to teaching means there is little or no opportunity for the students to express themselves or explore other ways of learning. Therefore, in Middle Eastern classrooms, discussions between class members are rarely encouraged and almost never take place (Marzouk, 2012).

It is no wonder, then, that a large proportion of the Kurdistan Region of Iraq's language learners struggle to attain a good standard of English and that they are often disillusioned with their education experience. For Jastad (2008) the problem lies with the fact that the Kurdistan Region of Iraq's educational set-up reinforces the idea that teachers are in charge and that students should just sit and listen to what they have to say. Meanwhile, Alsayid (2015) also found that Region's education system reinforced the hackneyed idea that those students who learned, in other words memorised, the most facts were obviously the best learners even though many of them did not question the material they were given to memorise. Indeed, it seems that Wahab's (2017) opinion is right; the curriculum has been designed in such a way that everyone who is educated by it thinks and behaves in the same way. In other words, it is specifically biased against individua1/independent/autonomous action.

\section{What does learner autonomy mean?}

As a term in its own right, 'learner autonomy' was first used in 1980 by Henri Holec, the man many consider the 'father' of the learner autonomy style to teaching language. Since its first introduction, however, numerous explanations have been given about what it is, all of which differ between writers, the context in which it is used, and any conclusions the educators debating the point reach. For Holec, learner autonomy was "the ability to take charge of one's learning” (Holec, 1980, p.3), which is not only pertinent but possibly the most widely alluded to description. As such, therefore, this quote is the bedrock of the concept, embodying as it does the key principle that it is essential learners take control of their own learning.

Learner autonomy - A diffe rence of opinion In spite of the fact that the Holec explanation of what learner autonomy is details every aspect of transferring learning from teachers to learners, many other language researchers disagree with it. Benson (2001, p.49), for example, does not believe Holec has accounted for "the nature of the cognitive capabilities underlying effective 
self-management of learning" while in 2008, Cotterall drew attention to two further points of contention. Firstly, his opinion was that Holec viewed autonomy as a dormant ability that learners needed to cultivate, while secondly, he felt that the definition overly concentrated on the technical parts of learning, particularly when it comes to introducing the methodological skill set necessary to the successful development of an individual's learning management abilities (Cotterall, 2008). For Little (2015), however, the difficulty he has with Holec's explanation is that "Learner autonomy is a problematic term" as "it is widely confused with self-destruction". His definition of autonomy is that it is a capacity: a capacity that enables an individual to develop skills in critical reflection, decision-making, detachment, and independent action (Little, 1991). This view is shared by Benson who, in his 2001 paper, reasoned that Little had added an essential psychological slant to Holec's original explanation as it defined autonomy as a process of learning that encompasses cognitive and selfmanagement processes.

Contrary to the above arguments about what autonomy is or is not, there is a general consensus about a definition that was included in a project report presented to the Council of Europe, which states that "autonomy is the ability to take charge of one's own learning" (Holec, 1980, p.3). This definition identifies autonomy as a proactive state in which an individual uses their initiative to formulate their own learning directions and reflections and thus "enables learners to organize resources autonomously in order to reach their goal" (Littlewood, cited in Chan, 2015, p.148). That said, Littlewood did make a distinction between proactive and reactive autonomous states. His view was that being proactively autonomous requires learners to establish their objectives, plan and choose the appropriate methods by which to meet those objectives, and evaluate their learning processes. In reactive autonomous learning, his opinion was that learners should not be self-directed but should respond to directions given to them. They are then required to manage their resources autonomously so that the learning objectives are met.

Other interpretations of autonomy such as Grolnick and Seal's (2007, p.132) regard it as "a sense of volition... the opposite of feeling controlled by someone else"; whereas for Deci and Ryan (1987, p.1025) it is an "action that is chosen; action for which one is responsible". As a consequence, the concept of autonomous language learning is often thought of by commentators such as Murray, Fuyishima and Uzuku (2014, p.81) as an approach that creates a "social learning space" in which individuals learn "with each other and from each other".

what is the role of motivation in developing le arner autonomy?

The large amount of investigative research that has been carried out on motivation and, indeed, motivating factors that affect second and foreign language learning outcomes indicate the level of interest there is about this subject. Scholars who have devoted much of their time trying to determine just how important it is to autonomy and autonomous learning include Dickinson (1995), Bowen (2012), Dörnyei (2012), Guilloteaux (2013) and Taylor (2013). That said; different researchers have different interpretations of motivation. Some, as with Biehler (1993), define it as a force that provides the stimulus for the inspiration, choice, orientation, and perpetuation of certain behaviours, as well as being considered by Dörnyei (1998) as a driving incite to teachinglearning process. Furthermore, for Williams and Burden (1997), motivation acts as a cognitive and emotional arousal trigger that results in the conscious decision to take action over something, which in turn stimulates individuals into periods of prolonged intellectual and/or physical exertion so that they can achieve their intended objectives. Thus, even though there are a number of ways in which motivation can be 
approached, it is undoubtedly one of the fundamental aspects governing the success or otherwise of those learning a second or foreign language.

\section{Linking motivation and learner autonomy}

The ties between motivation and that of autonomous learning have long been accepted as strong (Dörnyei, 2001b; Murray, Gao and Lamb, 2011), and for the majority of commentators such as Ushioda (2011) an accepted component of learning. In terms of how relevant motivation is to autonomy and vice versa researchers, like Benson (2001), are of the opinion that one reinforces the other and that "By taking control over their learning, learners develop motivational patterns". Consequently, helping learners to assume responsibility over their learning and regard themselves as the prime author in managing this process is integral to fostering a sense of persistence that will assist them to continue their learning. Moreover, there is a belief that autonomy increases motivation levels (Dörnyei, 2001b). As it is, the the connection between the two is sympathetic and unambiguous: encouraging learners to determine their own objectives and then the most appropriate actions in order to achieve them will, as a matter of course, motivate them to do just that. Lamb (2001) agrees, saying that allowing more learner autonomy enhances learners' motivation levels. Indeed, as mentioned the relationship is a symbiotic one; although Dam (1995) indicates learners are autonomous prior to becoming motivated, which he says occurs because they are encouraged to developed autonomous patterns of learning that then leads to an increase in their motivation levels. Nevertheless, this is not to suggest that this happens automatically. Research has discovered that the motivation-learner autonomy relationship is a complex one (Lamb, 2010) as the forces that act on one to empower the other are diverse in nature. Dörnyei (2001c), however, stresses that when the two do work in partnership their relationship and effectiveness is strengthened.

The significance of motivation in language learning

Hadfield and Dörnyei (2013) believe that language teachers frequently use the term motivation when they describe successful or unsuccessful learners. They also believe that without sufficient motivation even the cleverest learners are unlikely to persist long enough to attain any really useful language. Thus as so succinctly put it, motivation is a significant factor in foreign language learning. Gardner (2007), furthermore, says that without any motivating factors learners may not even begin to learn in the first place and for those who do, a lack of motivation could mean they find the process difficult, which means maintaining their momentum to learn is hard. Loima and Vibulphol's 2016 study investigated this by focusing on learners' levels of motivation and subsequent language attainment when they were taught in natural classroom environments. The research showed that when learners were able to decide which activities best suited their selfchosen learning objectives their motivation levels were high and their perception of how in control and responsible they were for their learning increased. This corresponds with Ryan and Deci's earlier 2000 research that concluded motivation is a powerful factor in the quest to make the learning process more effective and successful for learners.

Motivation is an indispensable quality that learners need if they are to be successful and persistent in their attempts to learn. Indeed, it is an especially important factor in the business of learning as this can often be a long-drawn out process. As such, autonomous learning is crucial in assisting learners to persist in their learning objectives, helping them to stay focused and selfdisciplined, and more able to take greater control over their learning needs. This is particularly true when they are, as Macaro (2008, p.56) puts it, 
faced with "external constraints and pressures". That said, other research has stressed the importance of motivation as one of the human mind's most basic determinants when it comes to how successful or otherwise learning environments are. Moreover, Reinders and Balcikanli (2011) suggest that learners who have high motivation levels may be more likely to seek out learning opportunities and be more effective at maintaining their levels of engagement with the whole process. This is backed up by Fan and Feng (2012) who found that highly motivated learners had a correspondingly higher attainment rate in their study on learners learning English as a second language than their less motivated colleagues.

Types of motivation: intrinsic and extrinsic For the motivational psychological field, the selfdetermination hypothesis proposed by Deci and Ryan (1985, 2002) has proved to be one of its most influential approaches. The terms most usually associated with it are intrinsic motivation and extrinsic motivation, with the premise being that learners are either intrinsically or extrinsically motivated to learn. Intrinsic motivation refers to an action being carried out because of the innate interest or enjoyment it gives as well as the satisfaction performing the action triggers. Conversely, extrinsic motivation refers to an action being carried out in order to achieve a tangible, external outcome rather than an intrinsically reinforcing reason such as gaining acceptance, receiving an award, or avoiding some form of sanction (Ryan and Deci, 2000).

Furthermore, there was an assumption that any autonomy support intervention would have a significant impact on learners' intrinsic motivation levels as they learned. This impact is represented by the variables effort, interest, and pressure. In addition, Deci and Ryan (1991) believe that intrinsic motivation is a necessary part of autonomy and being intrinsically motivated means learners have a desire to make their own decisions along with the freedom to fulfil that desire. Indeed, Farrell and Jacobs (2010) recommend that learners should be intrinsically motivated as this will have a great effect on how much they engage with the learning process, which in turn acts as the basis for increasing autonomous learning. Intrinsically motivated learners, as Garn and Jolly (2014) found, are also more process-oriented, while Dickinson (1995) discovered that learners with high intrinsic motivation levels were more likely to actively exercise autonomy in their learning, and Cho's 2012 research highlighted their greater persistence when learning. Moreover, terms such as authentic, genuine, and natural are often used in conjunction with intrinsic motivation in discussions about the subject. With regard to second language learning and acquisition, intrinsic motivation is most commonly thought of as a psychological condition that acts as a stimulus for learners to put into practice a target language for a specific purpose. Even though it is accepted that intrinsically motivated learners are more able at learning (Niemiec and Ryan, 2009), develop their skills better (Ling, 2013), and that intrinsic motivation is the foundation from which learners can act more autonomously, extrinsic motivation may also result in autonomous actions.

Indeed, occasionally, extrinsically motivated learners may carry out an action in anticipation of the outcome rather than with it having anything to do with the learning, according to Deci and Ryan (2008), and Niemiec and Ryan (2009). Thus, intrinsic and extrinsic motivation should not be thought of as mutually exclusive as learners may behave autonomously in one given situation but not in others. Consequently, some commentators such as Ushioda (2008) suggest that the two motivations can and do overlap regularly and that if activities start off as intrinsic then the rewards learners receive when they have completed them can contribute significantly to their internal satisfaction levels and overall learning. Regarding motivation and teaching 
behaviours, Jang, Kim and Reeve (2012) believe that how a teacher behaves plays an important part in influencing how learners develop their motivational skills. Littlewood's (1996) suggestion is to encourage teachers to take account of their learners' inbuilt confidence and motivation levels, and adopt a systematic approach to introducing them to the various recognised learning variables. Explaining the reasons why he feels it is so important that teachers encourage autonomous learning in their classrooms, Ushioda (2011, p.230) says it is "because we want to motivate out students and shape their identities". Therefore, teachers should try to show their learners the importance of learning a second language such as English by directly linking it with their own lives and to contexts outside of the learning environment. For Jang, Reeve and Deci (2010) the more freedom teachers can give their learners to fulfil their personal learning objectives, the more intrinsically motivated those learners become. As a consequence, then, the more learners perceive themselves as motivated, the more encouraged they will become to work harder and assume greater control over their learning.

\section{Methodology}

This section explains the methodological approach the study used to present justifications for the methodological choices that were made during the course of the research and support the philosophical foundation that the research methodology was founded on.

\section{Design of the study}

Undoubtedly, questionnaires are a highly effective strategy in so far as they can be distributed to a large number of participants even when they live in geographically diverse locations - and are relatively economical to administer as well as easily analysed (Dörnyei and Taguchi, 2012). Questionnaires are also able to gather a large quantity of data using limited resources and within tight timeframes; however, a purely quantitative approach would not have been able to capture every aspect of this study as Gillham (2000) cautions that the answers received may be insincere or superficial. Consequently, using a purely quantitative approach based on a statistical evaluation of the data collected from the questionnaires would not be able to fully comprehend the attitudes, feelings, and impressions of the respondents (Rubin and Rubin, 2012). Indeed, for a lot of people, filling in questionnaires is not something they enjoy and the temptation, according to Dörnyei (2003), is for them to select the answer that appeals to them most, rather than the one that is most truthful.

As Maxwell (2013) explained, it is clear then that the interview element is important and provides a valuable way for researchers to understand a respondent's actions. For Benson (2001), interviews are also useful for gaining an in-depth understanding of respondents' learning experiences and the contexts in which they took place: while Rubin and Rubin (2012) think interviews show the quantitative data in a more detailed and meaningful light.

The mixed-method approach, therefore, was considered the most appropriate tool for this research not only for the reasons given above but also because it is the strategy most usually recommended within the language learning field (Dörnyei, 2007). Indeed, combining different sets of data that have been collected at various stages of a research project can provide a detailed account of the subject under investigation (Creswell and Clark, 2011). Punch (2013) describes quantitative research as something that is normally guided by the researcher's area of interest, whereas qualitative research takes its starting point from the subject's perspective. That said; these can be combined successfully in a single research project.

\section{Participants}


The participants taking part in the research were comprised of 211 EFL learners who study English as a foreign language at Salahaddin, Sulaimani, and Duhok Universities. The research used 90 learners from Salahaddin University; 54 learners from Sulaimani University; and 67 learners from Duhok University. It should be pointed out that the study did not ask every teacher and learner from these Universities' English Language Departments to participate because, as Jackson (2016) states, in most instances it is neither feasible or indeed necessary to survey every person who is potentially ad rem.

When it came to the proficiency levels of those taking part in this research, and to ensure the learners participating were as homogeneous as possible, it was decided that only students majoring in English language and in their final 4th year of undergraduate studies would be selected. This was for two reasons: firstly, it is more likely that learners in their final year will engage with the feedback process, which for Brown (2007) suggests they have an increased sense of ownership regarding their learning and rates of progress. In addition, final year learners will be better able to provide a wide range of variables compared with their fellow 1st, 2nd, or 3rd year learners. The second reason for using only 4th year students is that learners in their final year spend the majority of their time studying in comparison to those in their 1st year, as well as concentrating more on deep learning activities than 2nd-year learners (Thomas et al., 2015). This means they may have a greater awareness about their learning levels, an understanding about which learning methods work best for them, and have developed learning for life attitude, which results in them being in a good position to make accurate reflections about their learning experience.

Out of the 211 students who participated in the questionnaire part of the study from across the three Universities, 47 volunteered to take part in the interviews. A random selection was then made and 24 were chosen to participate in the semi-structured interview process. The eventual interviewees were chosen as they fitted the basic criteria in that their participation was voluntary: although, gender was a consideration. Finally, the interviews were conducted using 14 males and 10 females.

\section{Data analysis process}

After collecting the data, statistical analyses were carried out on the questionnaires and processed through the Statistical Package for Social Sciences (SPSS) software - version 24, Windows operating platform. This meant the data underwent several statistical procedures. The items contained in the questionnaires were arranged using the Likert scale and given values from 1 to 5 . The respondents were required to indicate how much or how little they agreed with the statements laid out in the questionnaires with the format being: 1. strongly disagree, 2 . disagree, 3. undecided, 4. agree, and 5. strongly agree. Participants who selected values 4 and 5 were evaluated as expressing support for the statement, whereas those who selected 1 and 2 were evaluated as rejecting it. Those who selected value 3 were evaluated as neutral and thus, expressing no firm opinion.

Following on from the statistical descriptions stage, each section's qualitative data along with that collected from the learners' interviews were transcribed. This was analysed using King and Horrock's (2012) guidelines on qualitative data analysis, which suggests a three-step approach. This was duly applied in this study's analytical procedures. In the first step, descriptive coding was applied to the completely transcribed data. The second step involved applying interpretative coding to the data. In this technique, descriptive/defined codes that transcend the participants' actual words become grouped together. The final step comprised the allencompassing themes that made up the data analysis' key concepts. These themes arise from 
the descriptive and interpretative codes established in the previous two steps, although they contain higher rates of abstraction. Indeed, this part of the process involved carefully listening to and rereading the data to identify any essential factors that may have been missed before classifying them into a wider set of categories.

\section{Issues of validity and re liability}

Extra measures were put in place in order to ensure the study's validity: this included triangulation - the combining of methodologies within a single study to examine the same phenomenon. For the present research, this meant collecting data from both the questionnaires and interviews, in accordance with Jick's (1979) beliefs that compiling research material using a combination of methods is worthwhile even if there is no convergence between the data. It was able to come to some meaningful conclusions and verify the collected data's accuracy (Creswell, 2014), reliability, i.e. the results are understandable based on the data collected, and credibility, i.e. its participants had the requisite knowledge to provide relevant data (Merriam and Tisdell, 2016), this study drew heavily on the principles of construct validity. This is used to find out how accurately a tool measures what it is intended to measure. Indeed, construct validity is considered by some commentators such as Mislevy (2007) to be the most important of the validities believing as he does that it is the basis from which all other validity types are derived. Furthermore, from a scientific perspective, construct validity encompasses every aspect found in the other types of validity.

In terms of measuring the reliability of the questionnaires, the research employed the Cronbach alpha coefficient to make an estimation of the scale using the internal consistency method. This is a proven technique, and one that Brown (2001) says is the most frequently used when measuring consistency in questionnaires. That said; the present research still conducted a pilot study of the questionnaire using 24 learners and applying SPSS 24 to the results before using the Cronbach alpha coefficient to check the reliability of each variable that was identified. Following this, the researchers implemented the alpha if item deleted test in order to remove any items that were not likely to measure the same within the construct as the others in a scale (Dörnyei, 2007). This increased the reliability of the instrument, which raised the amount of confidence the researchers had in the research results. In keeping with Dörnyei's (2007) preferences, the research's tolerated reliability for all the sections relating to the learners had to cover a range of over .9 but not fall beneath .8. As a consequence, the results (0.916) proved the instruments were both consistent and reliable.

Table 1: Reliability Statistics

\begin{tabular}{cc} 
Cronbach's Alpha & N of Items \\
\hline 0.916 & 10 \\
\hline
\end{tabular}

Findings and Data Analysis

See table 2.

\section{Quantitative Analysis - Questionnaire}

By looking at the table above, it is obvious that the students consider motivation to be an important factor in the journey toward them becoming autonomous learners. Indeed, the lowest mean value of 3.99 recorded was more related to how importantly the students thought their universities viewed English with all the other questions scoring between 4.48 and 4.03. Questions 4 and 5 - new ranking 1 and 2 demonstrated the students' awareness of English as a valuable skill in terms of their future employment prospects and life opportunities (4.48 and 4.42, respectively). Equally rated with 
a mean score value of 4.27 , questions 2 and 8 new ranking 3 and $4-$ show that being interested in the subject and having teachers who listen to your needs and views are also important motivational factors. Question 3's mean score value of 4.21 , which gave it a new ranking of fifth, reflects how much value is given to the idea of belief, while questions 9 and 10's mean score value of 4.09 each show the importance of personal learning habits from the students' perspectives. Question 6 (4.14) demonstrates the need to take account of the things that directly influence students, which links in with question 7 (4.03) wherein "satisfaction from learning English" could be associated with learning by doing activities that interest and motivate. Looking at the results in the above table gives a good indication about how the participants view motivation as a significant factor in English language learning and its influence over the mission to make students autonomous learners.

\section{Qualitative Analys is - Interview}

From the qualitative analysis, it was obvious that the respondents considered learning English to be their top priority as reflected in its question's number one ranking. Only slightly lower in second place was the question relating to how good English language skills could help with job prospects and other life opportunities, which, again, a considerable proportion of the respondents agreed with "... you have great jobs after learning the language" and "There's no language that is more widely used than this." That said; this, however, was not the view of the majority with some very interestingly stating that they thought the language made them openminded and more inclined to explore cultures outside of their own “... students who doesn't know English, they are not interested in English culture. They are less open."

Discussing what teachers can do to motivate learning, respondents indicated that being praised for doing good work was an important motivational factor for them, although they did not want this to be indiscriminate. Mutual encouragement was also important, as was recognition that making mistakes was a normal part of learning and not something, they should feel bad about "explain that everyone makes mistakes". Teacher availability was part of this as well, alongside approachability with one respondent wanting assurance "that I can ask you any question and that I am not afraid of asking any question".

The part teachers play in motivating and encouraging their students preoccupied many of the interview respondents, with several of them strongly believing that their teachers could greatly influence their learning outcomes and thus, eventual level of learner autonomy "The teachers should examine the abilities of that student and he/she has to encourage that student and to tell him/her that the fields he needs to improve." However, the difficult subject of learning only to pass exams was also mentioned: "They teach you to memorize and go." This lead neatly into enquiries about how teachers can and do motivate their students and if using marks/grades as a tool is useful in this regard. There was mixed response to this idea with some agreeing it was a good tactic: 'I'm not sure if it's fair, but it's a good technique to threaten students"; while others thought a more balanced approach was a better option: "You have to learn real lessons of life instead of learning about marks."

All in all, in terms of this question, one respondent put it thus, 'I didn't like English department at all, but some of the teachers lift me up. And they made me love it. Because of those teachers, I want to be a teacher. I really want to." That said; the participants mentioned several obstacles that make teaching students to be autonomous learners difficult. One was the use of the students' first language, which often seemed to happen when undertaking tasks while another related to the lack of jobs once they had graduated "There are no jobs to do, nothing to do." One interviewee suggested that the students 
themselves might be the cause of some of the difficulties, as they do not necessarily want to become autonomous in their learning or they don't "want to be taught, who doesn't want to learn." Class sizes were also a concern alongside the passivity of some learners and, finally, the fact that some students are not willing to adapt their learning approach.

\section{Discussion}

Motivation is one of the fundamental features on which autonomous learning is founded and as such, the interrelation between the two is key to the concept's success (Ushioda, 2011). This interrelationship, therefore, has been one of the cornerstones of this research's investigations, particularly as it contributes to our knowledge that successful language acquisition is highly dependent on how much motivation students have, which is something that may be an intrinsic part of their personalities or simply gained through inspirational, external sources. Indeed, considering the viewpoints the study obtained from the participating students, it was clear that for those who were successful language learners developing their English skills had been and continued to be a personal battle. Moreover, it was a battle that required a consistently high level of commitment, motivation, and autonomy from them. Combining stimulating environments/activities into learning frameworks that acknowledge students' psychological needs to become autonomous has been shown to have a positive impact on their intrinsic motivation to learn. Consequently, encouraging students to be more empowered and engage in the reflective process could form the basis of a strategy that will steadily improve future learners' English language skills.

Undoubtedly, it this lack of intrinsic motivation that is the principle reason behind why students do not try harder to learn English. One possible explanation for this comes from listening to what the research participants said, which was that they believed most students are not intrinsically motivated or interested in becoming autonomous because the teaching they receive is only geared to making sure they pass their exams. Indeed, further investigation revealed that the major motivating factor for most of the students was to obtain a certificate rather than further their language skills. This short-term way of looking at learning as just something to pass an exam with must be changed to one where students want to learn for practical reasons, such as better future employment prospects. A second explanation for this lack of motivation is that some students felt inferior to their peers in terms of their levels of language proficiency. This is the fault of the education system, which insists they learn and use English but does not really have a clear-cut teaching policy to help them get the best out their learning meaning the result of this imposition is that students are left feeling they have no choice in the matter and are, in effect, powerless when it comes to their learning. An effective way to stimulate these unmotivated students is to create appropriate environments and situations that demonstrate to them the advantages attaining autonomous learning skills can offer them. Moreover, this should help them understand how important a tool English is not only for their own personal communication needs but globally, too, as well as opening their eyes to the opportunities good English-speaking skills can give them in terms of future employment prospects/career progression, and a better standard of living. That said; perhaps the most important reason for encouraging students to be more motivated is the need to make them take control of their personal learning agendas. Therefore, it should be made clear to them that if they can become motivated to develop an autonomous learning ethos they will have better learning outcomes than if they do not. In addition, their self-esteem will improve and their English language skills will advance to the level expected of university graduates.

In this research's particular case, it became clear that the students did not feel their teachers were 
good at motivating them. The reasons behind why the students felt dissatisfied and found their lessons uninspiring could be that often their interests and learning preferences are not taken into consideration when it comes to the practicalities of teaching language, in addition to the fact that classroom-centred teaching on its own is not able to give students a completely rounded learning experience. Autonomous learning, therefore, may offer a solution to this by showing the students alternative learning strategies that could inspire them and increase their desire to learn a foreign language. Thus, encouraging students to explore what learning autonomously could mean for their learning outcomes may act as the motivating force they need and encourage them to make full use of the various materials that are at their disposable. This will result in a marked improvement in their knowledge levels and language skills. Consequently, as the majority of the students who participated in this research indicated they understood how important the role motivation in their learning, therefore, the curriculum should highlight the practical benefits of autonomous learning and language proficiency. Furthermore, the education system should actively engineer its policies so that they emphatically demonstrate to learners the connection between linguistic competence and the continual development of their language skills. Another point to consider is that as English is now in many countries the language most associated with power and prestige, it is important for students to understand that they will need a good command of it if they wish to compete when they enter the working world. As a result, linking classroombased learning activities to authentic situations that occur outside that environment will greatly assist in getting students to understand that good language skills are useful and how being linguistically proficient is invaluable when it is applied in real life situations. Ultimately, motivating students to learn should motivate them to want to learn autonomously.
In the context of this research, the findings appear to confirm that there is a pressing need to improve students' motivation levels. The reason for this is that learners who are motivated are much more likely to identify with the aims of learning, meaning they will be more inclined to take responsibility for the end result. Indeed, motivation is representative of how fulfilled and satisfied a learner is with their learning experience as well as demonstrating their personal, wholehearted commitment to the whole learning process. As can be seen by the findings of this research, it appears that the students who need the most guidance from their teachers in terms of developing their language skills are those that are lacking in motivation, which is the necessary factor when it comes to taking control of their learning.

Based on the findings of this present research, there is one recommendation that can be made regarding motivation, which is that teachers should encourage all of their students to develop this characteristic either through their own innate desire to learn or by using other extrinsic means. The importance teachers have in the lives of their learners cannot be stressed enough, especially when it comes to motivation. As Lai and Ting (2013), Loima and Vibulphol (2014), and Urhahne (2015) all attest, teachers have the power to either fire up or dampen their learners' sense of motivation. Research has demonstrated that teachers who act in an autonomy-supportive way tend to produce learners whose motivation levels exceed those whose teachers are less supportive of autonomous learning. Moreover, Grolnick and Seal (2007) found that learners who have a natural inclination toward motivation were more persistent when pursuing their objectives and that they felt more competent when doing so. Thus, motivation plays an integral part in encouraging autonomous learning as well as being a key factor in how teachers manage learners' learning and behaviours. Furthermore, researchers such as Deci and Ryan (2000) discovered that an important determining 
factor for internal motivation is the perception that a learner has achieved a degree of autonomy. Consequently, teachers should aim to motivate their learners to continue learning even when they are not in the classroom, which would contribute to increasing their confidence with regard to their language and general communication skills. Similarly, Xu Jinfen and $\mathrm{Xu} \mathrm{Li} \mathrm{(2004)} \mathrm{agree} \mathrm{that} \mathrm{teachers} \mathrm{should} \mathrm{be}$ motivational when encouraging learners to learn; however, they caution that they should also take account of each learner's individual differences while trying to improve their autonomy.

Also essential is the atmosphere teachers create in their classrooms right at the start of the learning process. This should be an environment that inspires confidence and trust so the learners feel able to pursue their interests, express themselves freely, and make independent judgements about their learning. Indeed, when learners believe they are carrying out their learning activities autonomously, they automatically feel more in control. Reeve et al. (2007) concluded that when this happens, learners become noticeably more persistent and work harder. Engendering this type of positive learning environment requires teachers to motivate their learners through inspirational learning activities and techniques. Aside from this, Kohonen (1992, p.32) wants teachers to let learners know that they trust their abilities and appreciate the way they go about their decisionmaking. In his opinion, once this occurs, learners feel a sense of ownership and responsibility for their learning progress. It follows, therefore, that teachers who provide autonomy-supportive learning need to find ways of increasing their learners' internal motivation levels. Reeve, Bolt and Cai (1999) suggest they can do this by listening more to their learners and finding out what activities they feel would be of most use to them and what it is they want to achieve. In addition, teachers should allocate more time so that learners can increase how long they spend working independently.

\section{Conclusion}

The research results indicate that the students who seem to be the best at learning and using English are those who possess the most motivation to study. The findings also showed that when students are made aware of and understand the advantages to adopting an autonomous learning approach this encourages them to become ever more self-reliant. Another significant influence over how students regard their English language learning concerns the teacher-learner relationship. It is suggested, therefore, that from time-to-time it would a good idea for teachers to talk to their students on a more personal level. For instance, they could enquire about their students' language learning history and past experiences, find out if they are having any problems and help resolve them, and learn what activities they take part in away from the classroom so they can get a better idea of what skills the students are most interested in acquiring. Indeed, as devising ways of motivating students appears to be one of the key priorities for teachers, implementing these strategies should enthuse students about their language learning. Moreover, this would greatly help teachers to promote autonomous learning in their classrooms, as autonomy and motivation tend to go hand in glove. Perhaps more importantly, however, it has been observed that teachers seem to be more enthusiastic about teaching when the students in their classes are motivated.

\section{References}

1- Alsayid Mohammed, M.A. (2015) Peace Education in Iraqi Kurdistan Schools: An Analysis of Human Rights and History Education Curriculum. $\mathrm{PhD}$ thesis. Coventry: Coventry University, UK.

2- Benson, P. (2001). Teaching and Researching Autonomy in Language Learning. Harlow: Pearson Education. 
3- Benson, P. (2011) Teaching and researching autonomy in language learning. Applied linguistics in action series. Edinburgh Gate: Pearson Education.

4- Biehler, R.F. (1993) Psychology Applied to Teaching. 7th edn. Houghton Mifflin Company.

5- Bowen, J.A. (2012) Teaching naked: How moving technology out of your college classroom will improve student learning. San Francisco, CA: Jossey-Bass.

6- Brown, H.D. (2007) Principles of Language Learning and Teaching. 5th edn. USA: Pearson Longman.

7- Brown, J. D. (2001) Using surveys in language programs. Cambridge, England: Cambridge University Press.

8- Chan, M. (2015) 'Language Learner Autonomy and Learning Contract: A Case Study of Language Majors of a University in Hong Kong', Open Journal of Modern Linguistics, pp. 147-180.

9- Cho, Y. (2012) 'The relationship between L2 learning motivation and context among Korean EFL students', English Teaching, 67 (1), pp. 79-105.

10- Cotterall, S. (2008) 'Autonomy and good language learners', in C. Griffiths (ed.) Lessons from good language learners. Cambridge: Cambridge University Press, pp. 110-120.

11- Creswell, J. W. (2014) Research design: Qualitative, quantitative, and mixed methods approaches, (4th Ed.). Thousand Oaks, CA: SAGE Publications, Inc.

12- Creswell, J. W., \& Clark, V. L. P. (2011) Designing and conducting mixed methods research. Thousand Oaks, CA: Sage.

13- Dam, L. (1995) Learner autonomy: From theory to classroom practice. Dublin: Authentik.

14- Deci, E.L. and Ryan, R.M. (1985) Intrinsic motivation and self-determination in human behavior. New York, NY: Plenum.
15- Deci, E.L. and Ryan, R.M. (1987) 'The support of autonomy and the control of behavior', Journal of Personality and Social Psychology, 53, pp.

16- Deci, E.L. and Ryan, R.M. (1991) 'A motivational approach to self: Integration in personality', in R. Dienstbier (ed.) Nebraska Symposium on Motivation: Perspectives on motivation. Lincoln: University of Nebraska Press, vol. 38, pp. 237-288.

17- Deci, E.L. and Ryan, R.M. (eds) (2002). Handbook of Self-determination. Rochester, NY: University of Rochester Press.

18- Deci, E.L. and Ryan, R.M. (2008). 'Selfdetermination theory: A macrotheory of human motivation, development, and health. Canadian Psychology/Psychologie Canadienne, 49(3), pp. 182-185.

19- Dickinson, L. (1995) 'Autonomy and motivation: A literature review', System, 23, pp. 165-74.

20- Dörnyei, Z. (1998) 'Demotivation in foreign language learning'. Paper presented at the TESOL 98 Congress, Seattle, WA, March.

21- Dörnyei, Z. (2001b) Teaching and researching motivation. Harlow: Pearson Education Ltd.

Dörney, Z. (2001c) Motivational strategies in the language classroom. Cambridge: Cambridge University Press.

Dörnyei, Z. (2003) Questionnaires in second language research: Construction, administration, and processing. New Jersey: Lawrence Erlbaum.

22- Dörnyei, Z. (2007) Research methods in applied linguistics. Oxford: OUP.

23- Dörnyei, Z. (2012) Motivation in language learning. Shanghai: Shanghai Foreign Language Education Press.

24- Dörnyei, Z., \& Taguchi, T. (2010) Questionnaires in second language research: Construction, administration and processing (2nd Ed.). New York: Routledge.

25- Fan, J. and Feng, H. (2012) 'A study on students' learning motivation of EFL in 
Taiwanese vocational college', International Journal of Learning and Development, 2 (3), pp. 260-269.

26- Farrell, C. and Jacobs, M. (2010) Essentials for successful English language teaching. London: Continuum International Publishing.

27- Garn, A. and Jolly, J.L. (2014) 'High ability students' voices on learning motivation', Journal of Advanced Academics, 25 (1), pp. 7-24.

28- Gardner, R. (2007) 'Motivation and second language acquisition', Porta Linguarum, 8, pp. 9-20.

29- Gillham, B. (2000) Developing a questionnaire. London: Continuum

30- Grolnick, W.S. and Seal, K. (2007) Pressured parents, stressed-out kids: Dealing with competition while raising a successful child. New York, NY: Prometheus Books.

31- Guilloteaux, M.J. (2013) 'Language textbook selection: Using materials analysis from the perspective of SLA principles', Asia-Pacific Education Researcher, 22 (3), pp. 231-239.

32- Hadfield, J. and Dörnyei, Z. (2013) 'From research to implications. Motivation and the vision of knowing a second language', in Research and Resources in Language Teaching. Motivating Learning. Edinburgh: Pearson Education Limited, 1, p.1.

33- Hassan, A. and Jamaludin, N.S. (2010) 'Approaches and values in two gigantic educational philosophies: East and west', Online Educational Research Journal, 1 (2), pp. 1-15.

34- Holec, H. (1981) Autonomy and foreign language learning. Strasbourg: Council of Europe.

35- Jackson S. L. (2016) Research methods and statistics: a critical thinking approach, (5th Ed.). Belmont, CA: Cengage/Wadsworth.

36- Jang, H., Kim, E. J., \& Reeve, J. (2012) Longitudinal test of self-determination theory's motivation mediation model in a naturally occurring classroom context.
Journal of Education Psychology, 104, pp. 1175-1188.

37- Jang, H., Reeve, J., \& Deci, E. L. (2010) Engaging students in learning activities: It is not autonomy support or structure but autonomy support and structure. American Psychological Association, 102(3), pp. 588600.

38- Jastad, J.L. (2008) Memory, promise, and imagination in Iraqi Kurdistan: leadership in education policy development. $\mathrm{PhD}$ thesis, The University of San Francisco, San Francisco, California, USA.

39- Jick, T. D. (1979) Mixing qualitative and quantitative methods: Triangulation in Action. Administrative Science Quarterly, 24, 602-611.

40- King. N. and Horrock, C. (2012) Interviews in qualitative research. London, England. Sage.

41- Lamb, T. (2001) 'Metacognition and motivation - Learning to learn', in G.N. Chambers (ed.) Reflections on Motivation. London: CILT, pp. 85-93.

42- Kohonen, V. (1992) 'Experiental language learning: second language learning as cooperative learner education', in D. Nunan (ed.) Collaborative language learning and teaching. Cambridge: Cambridge University Press, pp. 14-39.

43- Lai, H.T. and Ting, K. (2013) 'English language learners' perception on motivational changes', English Language Teaching, 6 (8), pp. 10-20.

44- Lamb, T. (2010) 'Assessment of autonomy or assessment for autonomy? Evaluating learner autonomy for formative purposes', in A. Paran and L. Sercu (eds) Testing the Untestable in Language Education. Clevedon: Multilingual Matters, pp. 98-119.

45- Ling, Z. (2013) Research on learning motivation and autonomous L2 learning, International Conference on Educational Research and Sports Education (ERSE 2013) [Online]. Available at: 
http://dx.doi.org/10.2991/erse.2013.21

(Accessed: 11 October 2016).

46- Little, D. (1991) Learner Autonomy 1: Issues and Problems. Dublin: Authentik.

47- Little, D. (2015) Learner Autonomy and Second/Foreign Language Learning, LLAS Centre for Languages, Linguistics and Area Studies, Avenue Campus, Highfield, University of Southampton, Southampton [Online]. Available at: https://www.llas.ac.uk/resources/gpg/1409\#r ef2 (Accessed: 11 August 2016).

48- Littlewood, W. (1996) 'Autonomy: an anatomy and a framework', System, 24 (4), pp. 427-435 [Online]. Available at: https://www.sciencedirect.com/science/articl e/pii/S0346251X96000395 (Accessed: 18 August 2016).

49- Loima, J. and Vibulphol, J. (2014) 'Internal interest or external performing? A qualitative study on motivation and learning of 9th graders in Thailand basic education', Journal of Education and Learning, 3 (3), pp. 194203.

50- Loima, J. and Vibulphol, J. (2016) 'Learning and motivation in Thailand: A comparative regional study on basic education ninth graders', International Education Studies, 9 (1), pp. 31-43.

51- Lu, J. (2014) English Language Learning and Teaching in China - Students' Perspectives. New York: Untested Ideas Research Center.

52- Macaro, E. (2008) 'The shifting dimensions of language learner autonomy', in T. Lamb and H. Reinders (eds) Learner and teacher autonomy: Concepts, realities, and responses. Amsterdam: John Benjamins, pp. 47-62.

53- Marzouk, M.R. (2012) 'Teaching and Learning in Iraq: A Brief History', The Educational Forum, 76 (2), pp. 259-264.

54- Maxwell, J. A. (2013) Qualitative research design: An interactive approach (3rd Ed.). Thousand Oak, CA: Sage.
55- Merriam, S. B., and Tisdell, E. J. (2016) Qualitative research:A guide to design and implementation, (4th Ed.). San Francisco, CA: Jossey-Bass.

56- MHE. (2010) A Roadmap to Quality: Reforming the System of Higher Education and Scientific Research in the Kurdistan Region of Iraq. Erbil: Ministry of Higher Education and Scientific Research-KRG.

57- Mislevy, R. J. (2007) Validity by design. Educational Researcher, 36, 463469.

58- Murray, G., Fujishima, N. and Uzuka, M. (2014) 'Semiotics of place: Autonomy and space', in G. Murray (ed.) Social dimensions of autonomy in language learning. Basingstoke: Palgrave Macmillan, pp. 8199.

59- Murray, G., Gao, A. and Lamb, T. (eds) (2011) Identity, Motivation, and Autonomy in Language Learning. Bristol: Multilingual Matters.

60- Niemiec, C.P. and Ryan, R.M. (2009) 'Autonomy, Competence, and Relatedness in the Classroom Applying Self-Determination Theory to Educational Practice', Theory and Research in Education, 7, pp. 133-144.

61- Punch, K. F. (2013) Introduction to social research: Quantitative and qualitative approaches. London: Sage

62- Reeve, J., Bolt, E. and Cai, Y. (1999) 'Autonomy-supportive teachers: How they teach and motivate students', Journal of Educational Psychology, 91, pp. 537-548.

63- Reeve, J., Ryan, R.M., Deci, E.L. and Jang, H. (2007) 'Understanding and promoting autonomous self-regulation: A selfdetermination theory perspective', in $\mathrm{D}$. Schunk and B. Zimmerman (eds) Motivation and self-regulated learning: Theory, research, and application. Mahwah, NJ: Lawrence Erlbaum, pp. 223-244.

64- Reinders, H. and Balcikanli, C. (2011) 'Learning to foster autonomy: The role of teacher education materials', Reading. 
65- Ryan, R. M., \& Deci, E. L. (2000) Intrinsic and extrinsic motivations: Classic definitions and new directions. Contemporary Educational Psychology, 25(1), pp. 54-67.

66- Rubin, H. and Rubin, I. (2012) Qualitative interviewing: The art of hearing data, (3rd Ed.). Thousand Oaks, CA: SAGE Publications, Inc.

67- Thomas, L., Hockings, C., Ottaway, J., \& Jones, R. (2015) Independent learning: students' perspectives and experiences. Higher Education Academy. Available at https://www.heacademy.ac.uk/knowledgehub/independent-learning-studentperspectives-and-experiences. (Accessed: 6 April 2017).

68- Taylor, F. (2013) Self and identity in adolescent foreign language learning. Second language acquisition. Bristol: Multilingual Matters.

69- Urhahne, D. (2015) 'Teacher behavior as a mediator of the relationship between teacher judgment and students' motivation and emotion', Teaching and Teacher Education, 45 , pp. $73-82$.
70- Ushioda, E. (2008) 'Motivation and good language learners', in C. Griffiths (ed.) Lessons from good language learners. Cambridge: Cambridge University Press, pp. 19-34.

71- Ushioda, E. (2011) 'Motivating learners to speak as themselves', in G. Murray, X. Gao, $\mathrm{T}$. and Lamb (eds) Identity, motivation and autonomy in language learning. Second language acquisition. Bristol: Multilingual Matters, pp. 11-24.

72- Wahab, A. (2017) Education in Kurdistan Region at the Intersection of Nationalism and Democracy. $\mathrm{PhD}$ thesis, University of Toronto, Canada.

73- William, M. and Burden, R.L. (1997) Psychology for language teachers: A social constructivist approach. Cambridge: Cambridge University Press.

74- $\mathrm{Xu}, \mathrm{J}$. and $\mathrm{Xu}$ L. (2004) 'College English teachers' roles in learner autonomy', Journal of Higher Education Research, 3, pp. 81-84. 
Table 2: The role motivation plays in learner autonomy

\begin{tabular}{ccll}
\hline old rank & $\begin{array}{c}\text { New } \\
\text { rank }\end{array}$ & The role motivation plays in learner autonomy \\
\hline 4 & 1 & Q4. Nowadays, English is an important language to learn. & Mean \\
5 & 2 & Q5. Learning English can lead to good job opportunities \\
2 & 3 & Q2. Learning a language interests me. \\
8 & 4 & Q8. Teachers should listen carefully to their learners. \\
3 & 5 & Q3. Teachers should show they have faith in their students' abilities \\
6 & 6 & Q6. Teachers should take into consideration their students' interests. \\
9 & 7 & Q9. Language learners should research ways to help them learn successfully \\
10 & 8 & Q10. Teachers should share their own personal motivations for the language to their & 4.27 \\
7 & 9 & Q7. Learners will gain great satisfaction from learning English \\
4.09
\end{tabular}

